\title{
ナイアシン欠乏と皮膚免疫
}

\author{
杉田篤子，杉田和成
}

\section{Niacin deficiency and cutaneous immunity}

\author{
Atsuko Ikenouchi-Sugita and Kazunari SugitA \\ Swiss Institute of Allergy and Asthma Research, Davos, Switzerland
}

(Accepted November 12, 2014)

summary

\begin{abstract}
Niacin, also known as vitamin B3, is required for the synthesis of coenzymes, nicotinamide adenine dinucleotide (NAD) and nicotinamide adenine dinucleotide phosphate (NADP). Niacin binds with G protein-coupled receptor (GPR) 109A on cutaneous Langerhans cells and causes vasodilation with flushing in head and neck area. Niacin deficiency due to excessive alcohol consumption, certain drugs or inadequate uptake in diet causes pellagra, a photosensitivity dermatitis. Recently several studies have revealed the mechanism of photosensitivity in niacin deficiency, which may pave a way for new therapeutic approaches. The expression level of prostaglandin E synthase (PTGES) is up-regulated in the skin of both pellagra patients and niacin deficient pellagra mouse models. In addition, pellagra is mediated through prostaglandin $\mathrm{E}_{2}$-EP4 ( $\mathrm{PGE}_{2}$-EP4) signaling via reactive oxygen species (ROS) production in keratinocytes. In this article, we have reviewed the role of niacin in immunity and the mechanism of niacin deficiency-induced photosensitivity.
\end{abstract}

Key words_—_ niacin; G protein-coupled receptor (GPR) 109A; pellagra; prostaglandin (PG)

\section{抄 録}

ビタミン B3 として知られているナイアシンは, 生体内で補酵素として働く, nicotinamide adenine dinucleotide (NAD) と nicotinamide adenine dinucleotide phosphate（NADP）の合成に必須である。ナイアシンは皮膚ランゲルハ ンス細胞の G protein-coupled receptor（GPR）109A と結合し，ナイアシン攝取過多時は，頭頸部に血管拡張による フラッシングを誘発する。他方，ナイアシンの欠そは，アルコール依存症，薬剤，栄養不良などに起因し，ペラグ ラに代表される光線過敏症を起こす。したがって，ナイアシンの作用を明らかにすることは，光線過敏症のメカニ ズムの解明や新規治療ターゲットの探索の上で非常に重要である。最近，ペラグラ患者およびナイアシン欠乏ペラ グラマウスモデルでプロスタグランディン E 合成酵素（prostaglandin E synthase: PTGES）の発現が充進しているこ とが明らかになった。ささに、ペラグラによる光線過敏症は, prostaglandin $\mathrm{E}_{2}-\mathrm{EP} 4\left(\mathrm{PGE}_{2}-\mathrm{EP} 4\right)$ 受容体シグナルが 関与し，ケラチノサイトからの reactive oxygen species（ROS）を介して発症することが示唆された。本稿では，ナ イアシンの免疫における役割および, ナイアシン欠そによる光線過敏症のメカニズムについて述べる.

\section{はじめに}

ナイアシンは，ニコチン酸とニコチン酸アミドの 総称であり, ビタミン B3 とも呼ばれ, 糖質, 脂質, タンパク質の代謝に不可欠である。近年, こうした 本来のビタミンとしての作用以外に骨髄細胞分化に 必須であることが明らかになり，免疫学的にも注目 されている1).

臨床的にナイアシンは, その過多あるいは久乏に より皮膚症状を呈する ${ }^{2,3)}$ 。過剩摂取によるフラッ

Swiss Institute of Allergy and Asthma Research (SIAF)
シングは皮膚ランゲルハンス細胞の prostaglandin (PG) $\mathrm{D}_{2}$ が関与する ${ }^{3)}$. 他方，欠乏した場合には， 皮膚症状, 消化器症状, 精神症状を三徵とするいわ ゆるペラグラを発症する2). 皮膚症状は光線過敏性 の皮疹を生じるのが特徴で診断上重要な所見である が，その発症機序はこれまで不明であった。した がって，ナイアシン欠乏症における典型的な皮膚症 状である光線過敏症のメカニズムを明らかにするこ とは意義深い. ここでは, ナイアシンというビタミ ンファミリーに着目し, 生体内での意義と役割につ いて述べ，ナイアシン欠そ症とそのメカニズムにつ いて紹介する。 


$$
\text { ナイアシンとは }
$$

ナイアシンは, 1867 年 Huber がニコチン酸と名 付け, 1937 年 Elvehjem がアミド化された化合物 をニコチン酸アミドと命名したことにはじまる。 Elvehjem は犬の黒舌病（現在でいうナイアシン欠 乏症類似の疾患と思われる）をニコチン酸で治療 し，はじめてナイアシンのビタミン活性を示した。

ナイアシンは生体内において, エネルギー代謝と くにATP 産生に重要な役割を担っている。これを 直接担うのは，活性型のナイアシンでもある nicotinamide adenine dinucleotide (NAD) と nicotinamide adenine dinucleotide phosphate (NADP) という $2 つ$ の補酵素である ${ }^{4)}$ 。これらの活性型ナイアシンは, その前駆体である，ニコチン酸，ニコチン酸アミド， トリプトファンから合成される。トリプトファン由 来のナイアシン合成には, ビタミン B6, 亜鉛, 銅 なども関与し, $60 \mathrm{mg}$ のトリフトファンから $1 \mathrm{mg}$ のナイアシンが合成される，FAO/WHOによれば, 成人男女でそれぞれ $20 \mathrm{mg} / \mathrm{day}, 15 \mathrm{mg} /$ day のナイア シンを摂取するよう推奨している。

\section{ナイアシンの免疫学}

ナイアシンの受容体である GPR109A が発見され て以降, acipimox, acifran, MK-0345 など多くのアゴ ニストが合成され，ナイアシンの免疫系への作用が 明らかになってきた5,6).GPR109Aを介したナイア シンの作用には, 脂質代謝と抗炎症作用の 2 つがあ
る(図 1$)^{7)}$. GPR109A は脂肪細胞で高発現してい るが, 好中球, マクロファージ, ケラチノサイト, 皮膚ランゲルハンス細胞にも発現している ${ }^{8-11)}$ 。脂 肪細胞における, GPR109Aの活性化はアデニル酸 シクラーゼの抑制, cAMP/GRK 経路の抑制を誘導 する ${ }^{7)}$. その結果, 血中遊離脂肪酸低下, LDL 低下, HDL 増加, 中性脂肪低下をもたらす ${ }^{12,13)}$. GPR109A ノックアウトマウスにナイアシンを投与しても, ナ イアシンによる血中遊離脂肪酸低下作用はみられな いが, LDLなどの脂質への影響は保たれる うした事実は，ナイアシンが，GPR109A とは独立 した別の経路も介して作用していることを示唆して いる.

また, ナイアシンは抗炎症作用も有する7)。特に, 単球, マクロファージ, 脂肪細胞, 血管内皮細胞に ついてよく調べられている. ナイアシンの抗動脈 硬化作用は, 単球からの TNF- $\alpha$, IL-6, chemokine ligand 2 (CCL2) 産生抑制が関与していると考えら れている ${ }^{15,16)}$. 動脈硬化は単球やマクロファージな どによる炎症性疾患ともいえ, とりわけ, 単球と血 管内皮細胞との相互作用はその進展に重要と考えら れる。したがって, ナイアシンによる抗動脈硬化作 用は血管炎症の比較的早期に作用するのかもしれな い.

近年, 腸管免疫の領域では, 腸内細菌叢ーナイア シン-GPR109A の相互作用が明らかにされている ${ }^{17)}$. ナイアシンは腸管上皮細胞や樹状細胞, マクロ ファージに発現する GPR109A に作用し, IL-18 や

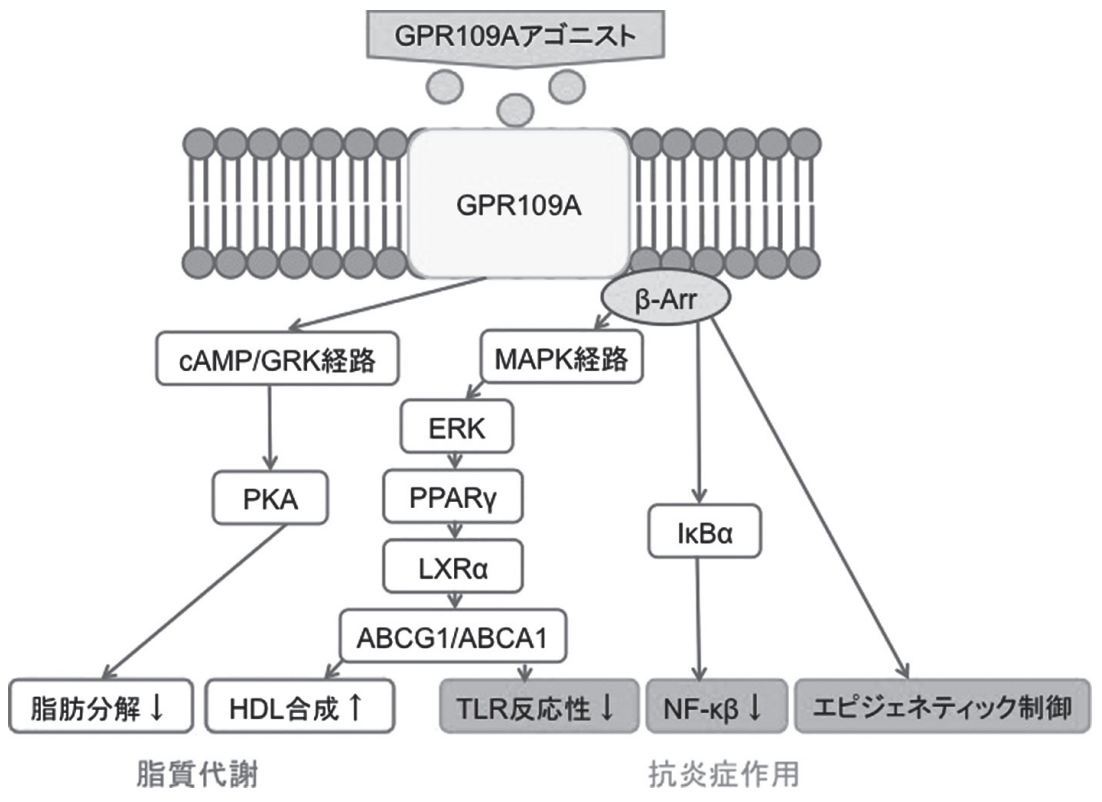

図 1 GPR109A を介した脂質代謝と抗炎症作用

GPR: G-protein-coupled receptor, $\beta$-Arr: $\beta$-arrestin. 文献 7 より改変. 
IL-10 産生を介して腸炎の制御に寄与していると考 えられている。 Singhらは, GPR109Aノックアウト マウスでは，IL-10 産生が低下し，粘膜固有層にお ける制御性 $\mathrm{T}$ 細胞（Treg）の数や割合も低下してい ることを示した ${ }^{17)}$ 。このことは GPR109A によるシ グナル伝達機構によって, IL-10 産生 T 細胞や Treg が制御されている可能性を示唆している。興味深い ことに, ナイアシンは, アンギオテンシン変換酵素 (ACE2) 欠損マウスで誘導される腸炎を起こりにく くする ${ }^{18)}$ 。さらに同マウスでは, ACE2 がレニン-ア ンギオテンシン系とは独立して，腸管における，ア ミノ酸代謝の維持, 腸内細菌叢の調整機能をもつこ とが明らかになっている。このマウスでは，小腸上 皮における mammalian target of rapamycin (mTOR) シグナルが低下し, 抗菌ペプチドなどの発現も減 弱していることが明らかになっている ${ }^{18)}$ 。つまり, ACE2 は，栄養状態の悪化による腸炎発症の重要な 分子機構を示していると考えられる。ささらに，神経 免疫の分野においても，ナイアシンは，重要な働き をもつ。とりわけ，脳梗塞のような慢性脳虚血の病 態では, ナイアシンは, マクロファージから $\mathrm{PGD}_{2}$ 産生を促し, 神経保護的に作用することが明らかに なっている ${ }^{19)}$.

\section{ナイアシン欠乏症}

ナイアシン欠そ症の背景となる疾患や病因は様々 である（図 2 ）。ナイアシンの摂取低下は，主にト ウモロコシを主食とする地域でみられるが, 先進国 ではアルコール依存症によるナイアシン久そが最も 多い20)。ナイアシンの消化吸収が低下する，クロー ン病, 消化管切除, 潰瘍性大腸炎でもナイアシン,

\section{ナイアシン欠乏症の病態}

ナイアシン欠乏の原因

1. ナイアシンあるいは前駆物質の摂取低下

2. 消化吸収低下ークローン病、消化管切除

3. アルコール依存症

4. トリプトファン・ニコチン酸代謝障害 (Hartnup病、肝硬変、HIV感染、カルチノイド症候群)

5. 消耗性疾患一重症潰瘍性大腸炎、慢性下痢

6. 薬剂性-INAH、6-MP、5-FU

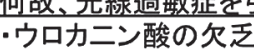

-NADやNADPの不足

・キヌレニン/キヌレン酸の蓄積

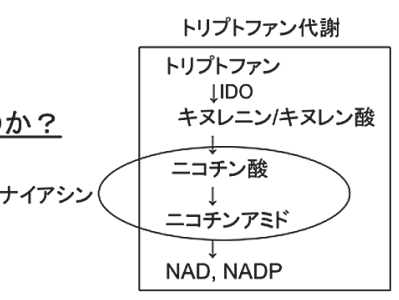

図 2 ナイアシン欠乏症の病態
トリプトファンの欠乏が起こりやすい ${ }^{21)}$.

薬剤にはナイアシン欠乏を誘発するものもあり, トリプトファンーキヌレニンーナイアシン経路のい ずれかを阻害する。特に，イソニアジドはビタミ ン B6 と構造が似ているため, ビタミン B6 に拮抗 した副作用も生じやすい ${ }^{22)}$. フルオロウラシル，ピ ラジナミド，フェノバルビタール，アザチオプリ ン, クロラムフェニコールもトリプトファンからナ イアシンへの変換を阻害することでペラグラを発 症することがある ${ }^{22)}$ 。ペラグラは HIV 感染症でも 報告があり ${ }^{23)}$ ，その機序として， HIV 感染細胞でナ イアシンが低下することに起因すると考えられてい る。しかし, 小児 HIV 感染症では, ナイアシン代 謝に異常はないとする報告もあり詳細は明らかでは ない24)、ペラグラ様皮疹を呈する疾患には，遺伝性 疾患もあり，その場合，Hartnup 病を念頭におく。

Hartnup 病は，小腸でトリプトファンなどアミノ酸 の吸収障害がみられるため, 尿中の中性アミノ酸值 が高值となる。小児期から日光露光部を中心に皮䖉 症状が出現し, 小脳失調, 複視, 知能低下などの精 神神経障害も順次出現する。2004 年, Harnup 病の 原因遺伝子が特定され, アミノ酸トランスポーター B0AT1（SLC6A19）の先天異常によって起こること が明らかになった

\section{ナイアシン欠乏による臨床症状}

ペラグラ（pellagra）は，イタリア語で皮膚（pella） と荒い（agra）を意味する。ペラグラの臨床的特徴 は 3D’s（dermatitis, diarrhea, dementia）といわれるよ うに，皮膚炎，下痢，認知症がみられる。これらに death を加え 4D’s と呼ぶこともある。ペラグラは, 依然, 発展途上国において重大な健康問題であり, 先進国においても，薬物依存症やアルコール依存症 患者を中心にみられる。

\section{ナイアシン欠乏による皮膚症状}

ペラグラの最も重要な皮膚症状は光線過敏性皮疹 である ${ }^{2)}$. 光線過敏症は日光露光部, 顔面, 前頸部, 前腕から手背にかけて左右対称に皮疹がみられる （図 3 ）。加えて，瘙痒，灼熱感を伴い，皮疹は紫紅 色調を呈し，びらん，潰瘍に至り，一部は水疱を形 成する。特に前頸部に首飾り様にみえる, 色素沈着 は Casal's necklace と呼ばれ診断上，重要な所見で ある ${ }^{21)}$. 下腿部でも光線による暴露があれば皮疹を 認める。ペラグラはその初期に紅斑や浮腫を特徵と 

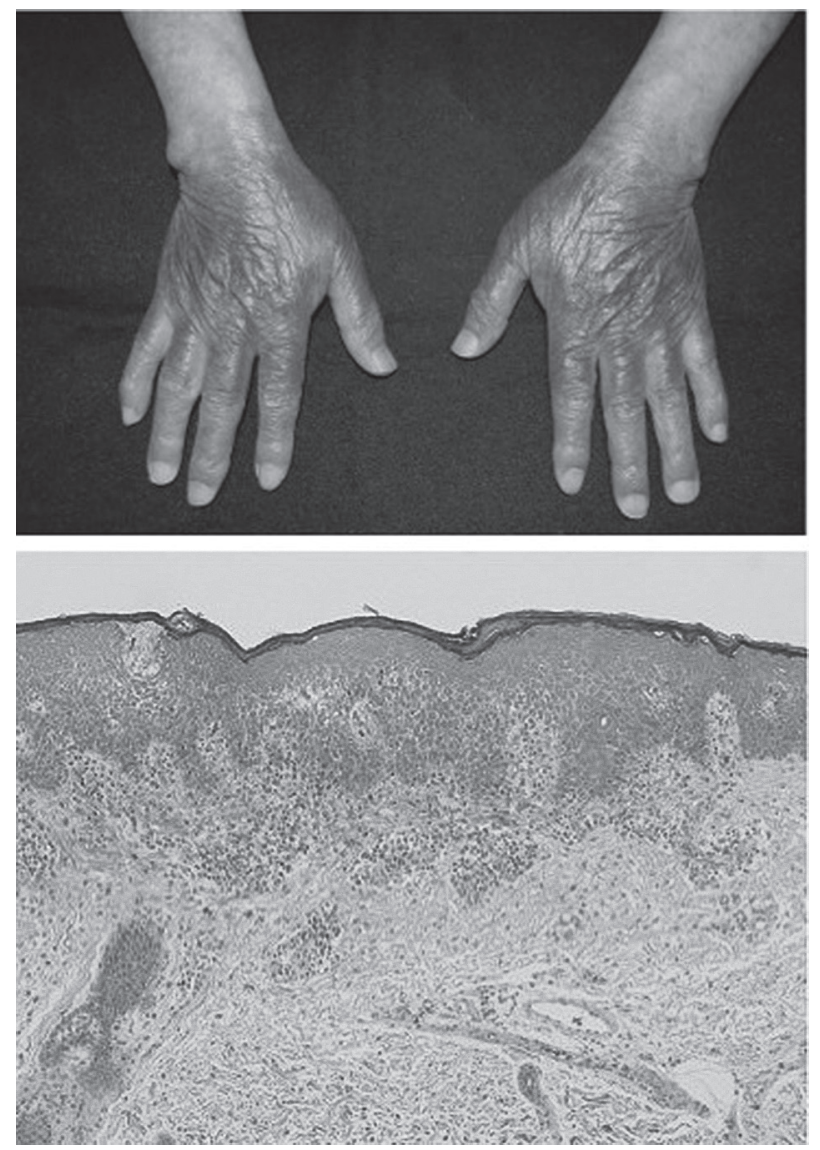

図 3 ペラグラの臨床像と組織像

する, いわゆる日焼けに近い臨床像を呈し, 病理組 織学的に, 液状変性や血管周囲のリンパ球浸潤など 非特異的な炎症反応を認める（図 3 ).

慢性に経過するにつれ, 皮疹は乾燥し後に色素沈 着や色素脱失が顕著となる, いわゆる多形皮膚萎縮 をきたす，皮膚症状は，非露光部にもみられ，粘膜， 外院部に皮疹を認める。外院部は, 紅斑, びらんが みられ，ときに二次感染を伴う。なお，Hartnup 病 や薬刘性のペラグラでは, こうした粘膜, 外陰部の 皮疹は報告されていない，他にも，ペラグラでは，

肘, 膝, 足関節部など骨隆起部に皮虐症状を認める ことがある. 角化性病変と色素沈着を特徵とするが, 光線過敏性の皮疹と比べ，その変化にそしい，ペラ

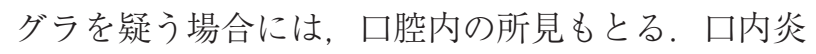
や舌では偽粘膜性の譬やびらん, 潰瘍を生じる. 特 に, 舌炎は $90 \%$ 以上の患者でみられるという報告 もある ${ }^{26)}$.さらに，爪の変形，脱毛を伴うこともあ る。皮膚症状以外には, 腹痛, 下痢がみられ，しび れや知覚過敏など末梢神経障害を伴い, 後に妄想, 認知症が出現する ${ }^{27)}$.

ペラグラの診断には，病歴，皮膚症状，病理所見
に基づき，他に鑑別すべき光線過敏症を除外し，診 断する，血中，尿中のニコチン酸值が低值を示した 場合にも本症を疑う。光線過敏症の確定診断には光 線テストが有用である ${ }^{28)}$. 反応を起こす光の波長を 作用波長と呼ぶが, 光アレルギーの場合, 多くは UVA であり，例外的にUVB のこともある。ペラグ ラの光線過敏性皮疹の場合, 光線テストの結果は, 正常域あるいは，作用波長が UVA, UVB，可視光線 という報告もあり，コンセンサスは得られていな い29). 治療はニコチン酸, ニコチン酸アミドの投与 を行い, 原因の除去が重要である.

\section{ナイアシン欠乏による光線過敏症発症メカニズム}

光線過敏症は通常, 健常人の皮虐に異常を呈さな い程度の光線照射で照射部位に異常な反応を呈する 疾患である。したがって, 通常より少ない線量で生 じた場合，光線過敏症と捉える，ナイアシン欠乏に よる光線過敏症が生じるメカニズムとして, これ まで主に，3つの説（ウロカニン酸の欠そ, NAD, NADP の不足, キヌレン酸の蓄積）が提唱されてき た。

ウロカニン酸はヒスチダーゼにより合成され，大 部分は皮膚の角層内に存在し, 紫外線によるDNA 損傷を防ぐ役割を担う ${ }^{30)}$. ナイアシン欠乏症の皮膚 はウロカニン酸やヒスチダーゼ活性が低いことがわ かって㧍り, 紫外線防御能の低下により光線過敏症 を発症すると考えられてきだ11)、ヒスチジン血症は ヒスチダーゼが先天的に欠損するが，ヒスチジン血 症をきたすマウスの場合, 角層中のウロカニン酸の 低下がみられ，UVBによる紫外性皮膚障害を誘発 する ${ }^{32}$ 。さらに, ウロカニン酸を皮膚に塗布すると, UVB によるDNA 損傷を低下させる。しかしなが ら, ヒスチジン血症では, 角層中のウロカニン酸が 久乏するにもかかわらず，紫外線感受性は高まらな いため, 更なる検討が必要といえるだろう ${ }^{33)}$. 他方, ナイアシンの前駆体である, NAD, NADPは, 紫外 線の吸収に関与する。そのため, これらの欠乏が光 線による皮膚障害を誘発するという説もある34)。 う一つは, トリプトファンーナイアシン経路におけ る, キヌレン酸の蓄積である. キヌレン酸は光感作 物質と考えられており，ナイアシン欠乏によるキ又 レン酸の蓄積が光線過敏症を誘導するという考え方 である ${ }^{35)}$.

このように, ナイアシン欠そ症による皮膚炎形成 メカニズムはいくつかの有力な説があるものの, ナ 
イアシン欠そによる光線過敏症のメカニズムは明ら かになっていなかった，換言すれば，光線過敏症は 種々のサイトカインや一酸化窒素などを介して紅斑 が形成されるものの，ナイアシン欠乏症に沶ける皮 膚炎形成の責任分子は不明であった ${ }^{29,36)}$.

そこで我々は，ナイアシン欠乏症に打ける光線過 敏症のメカニズムを解明するため, ナイアシン久乏 マウスを用いて検討した。ナイアシン欠そ食を与え たC $57 \mathrm{BL} / 6$ マウスにUVB $5 \mathrm{~kJ} / \mathrm{m}^{2}$ を照射し，照射 後のマウス耳介厚を測定し, 組織学的に検討した。

UVB 照射後，通常食では照射後 5 日をピークに皮 䖉炎は減弱するが，ナイアシン欠そマウスでは，紫 外線皮膚炎が遷延することが明らかになった（図 4 ）。 病理組織学的にも表皮の肥厚や炎症細胞浸潤が顕著 であった。これらの所見はナイアシンアンタゴニス 卜を用いた実験でも同様の結果であった。

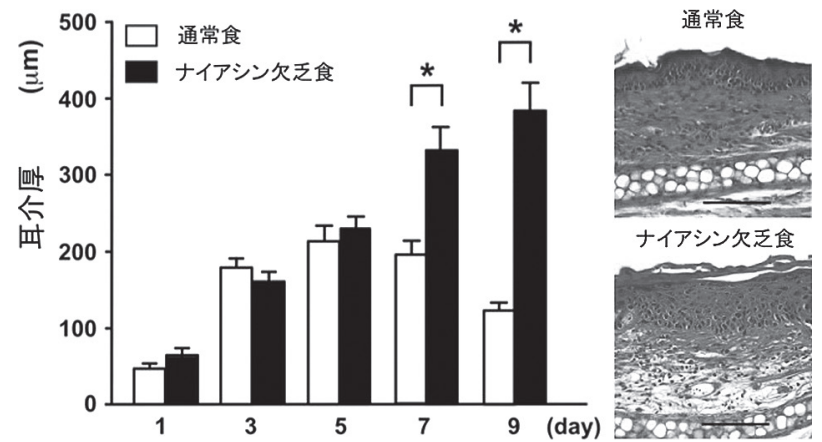

図 4 紫外線照射後の耳介厚と組織像 *, $P<0.05$. Scale bar $100 \mu \mathrm{m}$. 文献 29 より改変
興味深いことに，紫外線照射後のナイアシン欠そ 状態の皮膚でプロスタグランディン $\mathrm{E}$ 合成酵素の mRNA（Ptges）発現が充進し，シクロオキシゲナー ゼ-2 (cyclooxygenase-2: COX-2) 阻害薬により紫外 線皮膚炎が減弱した。これらのことから，ナイアシ ン欠そによる光線過敏症はプロスタノイド合成系や その受容体が関与することが示唆された。プロスタ ノイドは PG とトロンボキサン (thromboxane: TX) よりなる。プロスタノイドは, アラキドン酸が細胞 膜リン脂質より放出されることで合成され，COX により $\mathrm{PGH}_{2}$ となる。次いで，各合成酵素により $\mathrm{PGE}_{2}, \mathrm{PGD}_{2}, \mathrm{PGF}_{2 \alpha}, \mathrm{PGI}_{2}, \mathrm{TXA}_{2}$ が合成される ${ }^{37}$. プロスタノイドは合成されるとすぐに細胞外に放出 されるが，生理的に不安定なため，局所でのみ作用 する。 これらのうち, ペラグラの光線過敏症では, Ptges 発現が六進する ${ }^{29)}$ ．さらに，ペラグラ患者皮 膚では健常人の皮膚と比べ，プロスタグランディン E 合成酵素（prostaglandin E synthase: PTGES）が顕 著に発現していた（図 5 )。これらのことから、ぺ ラグラの病態への $\mathrm{PGE}_{2}$ の関与が明らかになった。 実際，Ptges 欠損マウスでは紫外線皮膚炎が減弱し 皮膚血流量も減少した。一般に，プロスタノイドは 標的細胞に存在する $\mathrm{G}$ 蛋白結合型受容体を介して 作用を発揮するが, PGE 受容体は EP と名付けられ, $\mathrm{EP} 1, \mathrm{EP} 2, \mathrm{EP} 3, \mathrm{EP} 4$ の 4 種類のサブタイプの受容 体が知られている ${ }^{38)}$ ，そこで，ペラグラの光線過敏 症の責任受容体を同定するため, これらの久損マウ

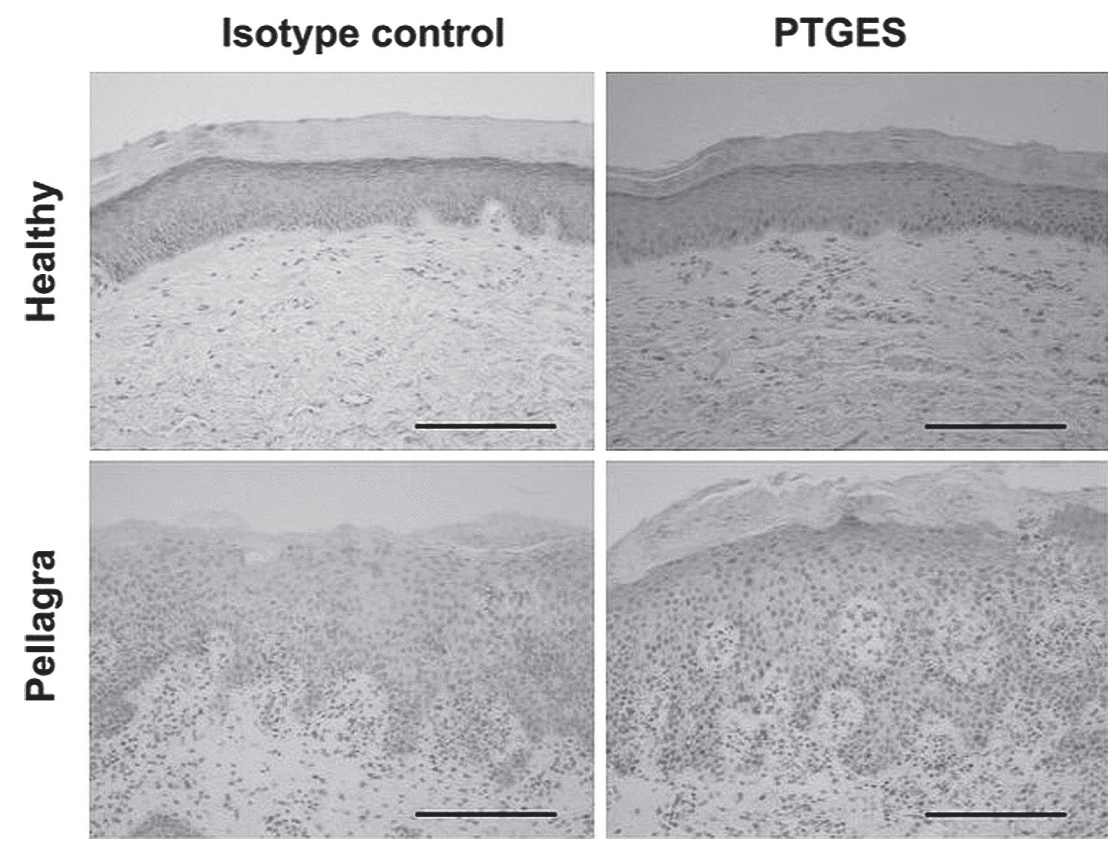

図 5 ヒトペラグラの PTGES 発現

Scale bar $100 \mu \mathrm{m}$. PTGES: prostaglandin E synthase. 文献 29 より改変. 
スや拮抗薬を用いた。 その結果, EP4 受容体拮抗薬 を投与したマウスでは, 紫外線皮膚炎が減弱するこ とが明らかになった（図6）。

以上の結果から, ナイアシン久そ下での光線過敏 症の発症に $\mathrm{PGE}_{2}$-EP4 シグナルが関与することが示 唆された。ナイアシン欠そ状態では, ケラチノサイ トからの ROS の産生が充進し，N-アセチル-L-シス テイン（NAC）により阻害される。他方，ナイア シン欠そマウスに，インドメタシンを投与すると， $\operatorname{ROS}$ の産生が減少することから, 光線過敏症の機 序には PGE 2 -EP4 シグナルと ROS の産生立進も関 与することが明らかになった（図 7 )。ペラグラは 皮膚炎だけでなく，腸炎もみられる，我々のモデ ルマウスでは，腸管の Ptgs2（COX-2）およびPtges の発現が上昇していたものの, インドメタシン投与 で下痢は改善しなかった。このことは，腸炎は， $\mathrm{PGE}_{2}$ 以外の経路が関与している可能性が示唆された。

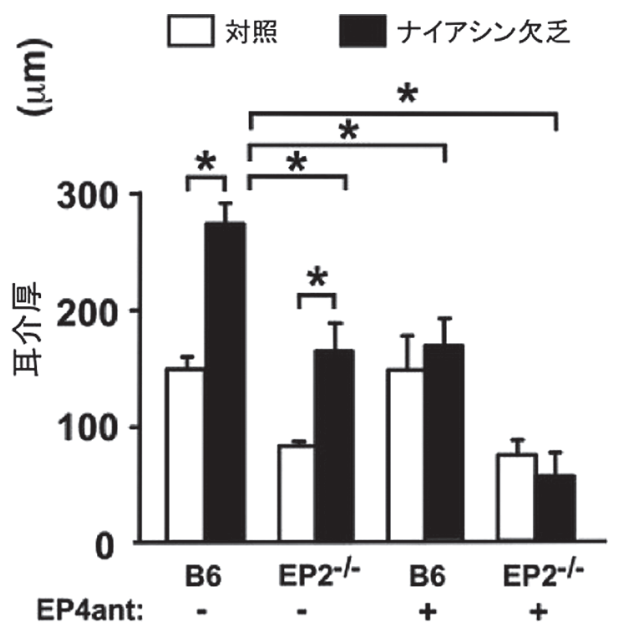

図 6 EP2 ノックアウトマウス, EP4 拮抗薬投与下での 紫外線照射後耳介厚

*, $P<0.05$. B6: C57BL/6, EP4ant: EP4 antagonist. 文献 29 よ り改変.

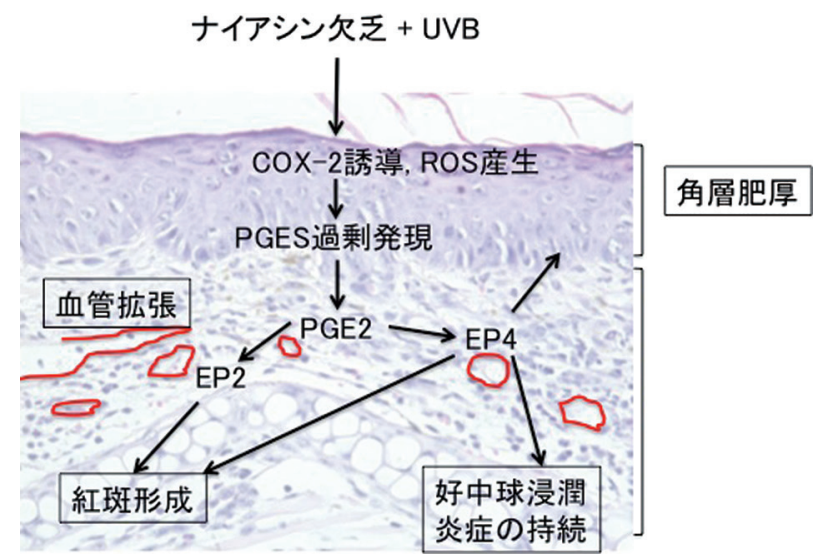

図 7 ナイアシン欠乏による光線過敏症発症メカニズム
最後に, $\mathrm{PGE}_{2}$ の関与する光線過敏症として色素 性乾皮症も明記しておきたい。色素性乾皮症は常染 色体劣性の遺伝性疾患で DNA 修復機能が低下寸る ことで光線過敏症や皮膚がんを発生する ${ }^{39)}$ 。色素性 乾皮症の原因遺伝子である, xeroderma pigmentosum group A（XPA） 欠損マウスの研究から, $\mathrm{PGE}_{2}$ が光 線過敏症の発症に関与することが明らかになった。 このマウスは紫外線照射後, 皮膚のPtgs2 発現が卉 進する ${ }^{40)}$ 。他方，ナイアシンはNAD や NADP の前 駆物質であるため，紫外線によるDNA 損傷の修復 にも寄与すると思われる。したがって，ナイアシン 欠乏による NAD や NADP の低下が DNA を損傷し， Ptgs2 を誘導した可能性も考えられた。

\section{おわりに}

ビタミンファミリーであるナイアシンは, 実に 様々な免疫応答に関与する。ここでは主に, ナイア シン欠乏症の病態, 臨床症状について述べ, その代 表的な疾患であるぺラグラのメカニズムについて解 説した。ペラグラは世界的に未解決の代謝性疾患で あり，重篤な光線過敏症を起こす。ペラグラの皮膚 炎が日光露光部や間擦部を中心にみられることから， UVBをはじめとした外的刺激が，ナイアシン欠乏 状態で $\mathrm{PGE}_{2}$ や ROS 産生を誘導しているのかもし れない，皮膚炎，腸炎，脳炎に共通のメカニズムが 背景にある可能性もあり, 今後, さらなる研究が期 待できる。

\section{謝辞}

研究の機会を与えて下さった, 浜松医科大学戸倉 新樹教授, 産業医科大学中村元信教授, 京都大学大 学院医学研究科椛島健治先生に感謝致します。

\section{文献}

1) Skokowa, J., et al.: NAMPT is essential for the G-CSF-induced myeloid differentiation via a NAD(+)-sirtuin-1-dependent pathway. Nat Med. 15: 151-158, 2009.

2) Mercieri, M., Mercieri, A.: Images in clinical medicine: A photosensitive dermatitis in the intensive care unit. N Engl J Med. 364: 361, 2011.

3) Dunbar, R.L., Gelfand, J.M.: Seeing red: flushing out instigators of niacin-associated skin toxicity. $J$ Clin Invest. 120: 2651-2655, 2010.

4) Benavente, C.A., et al.: NAD in skin: therapeutic approaches for niacin. Curr Pharm Des. 15: 29- 
38, 2009.

5) Offermanns, S., et al.: International Union of Basic and Clinical Pharmacology. LXXXII: Nomenclature and Classification of Hydroxy-carboxylic Acid Receptors (GPR81, GPR109A, and GPR109B). Pharmacol Rev. 63: 269-290, 2011.

6) Soga, T., et al.: Molecular identification of nicotinic acid receptor. Biochem Biophys Res Commun. 303: 364-369, 2003.

7) Chai, J.T., et al.: GPR109A and vascular inflammation. Curr Atheroscler Rep. 15: 325, 2013.

8) Yousefi, S., et al.: cDNA representational difference analysis of human neutrophils stimulated by GM-CSF. Biochem Biophys Res Commun. 277: 401-409, 2000.

9) Schaub, A., et al.: PUMA-G, an IFN-gammainducible gene in macrophages is a novel member of the seven transmembrane spanning receptor superfamily. Eur J Immunol. 31: 3714-3725, 2001.

10) Hanson, J., et al.: Nicotinic acid- and monomethyl fumarate-induced flushing involves GPR109A expressed by keratinocytes and COX-2-dependent prostanoid formation in mice. J Clin Invest. 120: 2910-2919, 2010.

11) Chai, J.T., et al.: Nicotinic acid receptor GPR109A is down-regulated in human macrophage-derived foam cells. PLoS One. 8: e62934, 2013.

12) Ding, Y., et al.: Effect of niacin on lipids and glucose in patients with type 2 diabetes: A metaanalysis of randomized, controlled clinical trials. Clin Nutr, 2014.

13) Altschul, R., et al.: Influence of nicotinic acid on serum cholesterol in man. Arch Biochem Biophys. 54: 558-559, 1955.

14) Lauring, B., et al.: Niacin lipid efficacy is independent of both the niacin receptor GPR109A and free fatty acid suppression. Sci Transl Med. 4: 148ra115, 2012.

15) Lukasova, M., et al.: Nicotinic acid (niacin): new lipid-independent mechanisms of action and therapeutic potentials. Trends Pharmacol Sci. 32: 700707, 2011.

16) Digby, J.E., et al.: Anti-inflammatory effects of nicotinic acid in adipocytes demonstrated by suppression of fractalkine, RANTES, and MCP-1 and upregulation of adiponectin. Atherosclerosis. 209: 89-95, 2010.

17) Singh, N., et al.: Activation of Gpr109a, receptor for niacin and the commensal metabolite butyrate, suppresses colonic inflammation and carcinogenesis. Immunity. 40: 128-139, 2014.
18) Hashimoto, T., et al.: ACE2 links amino acid malnutrition to microbial ecology and intestinal inflammation. Nature. 487: 477-481, 2012.

19) Rahman, M., et al.: The beta-hydroxybutyrate receptor HCA2 activates a neuroprotective subset of macrophages. Nat Commun. 5: 3944, 2014.

20) Ishii, N., Nishihara, Y.: Pellagra among chronic alcoholics: clinical and pathological study of 20 necropsy cases. J Neurol Neurosurg Psychiatry. 44: 209-215, 1981.

21) Hegyi, J., et al.: Pellagra: dermatitis, dementia, and diarrhea. Int J Dermatol. 43: 1-5, 2004.

22) Wan, P., et al.: Pellagra: a review with emphasis on photosensitivity. Br J Dermatol. 164: 1188-1200, 2011.

23) Murray, M.F., et al.: HIV infection decreases intracellular nicotinamide adenine dinucleotide [NAD]. Biochem Biophys Res Commun. 212: 126-131, 1995.

24) Tremeschin, M.H., et al.: Niacin nutritional status in HIV type 1-positive children: preliminary data. J Pediatr Gastroenterol Nutr. 44: 629-633, 2007.

25) Seow, H.F., et al.: Hartnup disorder is caused by mutations in the gene encoding the neutral amino acid transporter SLC6A19. Nat Genet. 36: 10031007, 2004.

26) Kiss, F., Anstey, A.V.: A review of UVB-mediated photosensitivity disorders. Photochem Photobiol Sci. 12: 37-46, 2013.

27) Karthikeyan, K., Thappa, D.M.: Pellagra and skin. Int J Dermatol. 41: 476-481, 2002.

28) Sugita, K., et al.: Chronic actinic dermatitis associated with adult T-cell leukemia. J Am Acad Dermatol. 52: 38-40, 2005.

29) Sugita, K., et al.: Prostaglandin E(2) is critical for the development of niacin-deficiency-induced photosensitivity via ROS production. Sci Rep. 3: 2973, 2013.

30) Yamaguchi, T., et al.: Galectin-7, induced by cisurocanic acid and ultraviolet $\mathrm{B}$ irradiation, downmodulates cytokine production by $\mathrm{T}$ lymphocytes. Exp Dermatol. 22: 840-842, 2013.

31) Vasantha, L.: Histidine urocanic acid and histidine alpha-deaminase in the stratum corneum in pellagrins. Indian J Med Res. 58: 1079-1084, 1970.

32) Barresi, C., et al.: Increased sensitivity of histidinemic mice to UVB radiation suggests a crucial role of endogenous urocanic acid in photoprotection. $J$ Invest Dermatol. 131: 188-194, 2011.

33) Baden, H.P., et al.: Epidermis in histidinemia. Arch Dermatol. 100: 432-435, 1969. 
34) Rapaport, M.J.: Pellagra in a patient with anorexia nervosa. Arch Dermatol. 121: 255-257, 1985.

35) Wennersten, G., Brunk, U.: Cellular aspects of phototoxic reactions induced by kynurenic acid. I. Establishment of an experimental model utilizing in vitro cultivated cells. Acta Derm Venereol. 57: 201-209, 1977.

36) Kabashima, K., et al.: Prostaglandin E2 is required for ultraviolet B-induced skin inflammation via EP2 and EP4 receptors. Lab Invest. 87: 49-55, 2007.

37) Kabashima, K., Miyachi, Y.: Prostanoids in the cutaneous immune response. J Dermatol Sci. 34: 177-184, 2004.
38) Honda, T., et al.: Prostanoid receptors as possible targets for anti-allergic drugs: recent advances in prostanoids on allergy and immunology. Curr Drug Targets. 11: 1605-1613, 2010.

39) Nakane, H., et al.: High incidence of ultravioletB-or chemical-carcinogen-induced skin tumours in mice lacking the xeroderma pigmentosum group A gene. Nature. 377: 165-168, 1995.

40) Kuwamoto, K., et al.: Possible involvement of enhanced prostaglandin E2 production in the photosensitivity in xeroderma pigmentosum group A model mice. J Invest Dermatol. 114: 241-246, 2000 . 